University of South Carolina

Scholar Commons

$12-2004$

\title{
The Role of Normative Political Ideology in Consumer Behavior
}

David Crockett

University of South Carolina - Columbia, dcrockett@moore.sc.edu

Melanie Wallendorf

Follow this and additional works at: https://scholarcommons.sc.edu/mark_facpub

Part of the Marketing Commons

\section{Publication Info}

The Journal of Consumer Research, Volume 31, Issue 3, 2004, pages 511-528.

http://jcr.wisc.edu/

(C) 2004 by Journal of Consumer Research, Inc.

This Article is brought to you by the Marketing Department at Scholar Commons. It has been accepted for inclusion in Faculty Publications by an authorized administrator of Scholar Commons. For more information, please contact digres@mailbox.sc.edu. 


\title{
The Role of Normative Political Ideology in Consumer Behavior
}

\author{
DAVID CROCKETT \\ MELANIE WALLENDORF*
}

\begin{abstract}
This study of African-American consumers living in a large racially segregated midwestern city adds to extant theory on ideology in consumer behavior by considering the role of normative political ideology in provisioning. The specifi roles of traditional black liberal and black nationalist political ideologies are discussed. We conclude that normative political ideology is central to understanding shopping as an expression of social and political relations between households confronting attenuated access to goods and services, ranging from housing to food, in a setting stratifie by gender, race, and class. Beyond the specific of this demographic group and setting, we suggest that contemporary consumption in the United States is a primary arena in which political ideology is expressed and constructed.
\end{abstract}

$\mathrm{N}_{\mathrm{o}}$ ormative political ideology is very much at the heart of consumer behavior. Examples abound of consumption choices that are structured by, and which in turn structure, considerations that most would label as both political and ideological. The radical critiques of Western consumer culture offered by the anticorporate/antiglobalization/antibranding and voluntary simplicity movement(s) certainly serve as contemporary exemplars of this phenomenon (see Elgin 2000). Consider as well the role of political ideology in typical decisions any consumer might make to buy an "American" car or to disavow the purchase of toy guns for children or to place retirement savings in "socially conscious" investment accounts that avoid stocks in tobacco fi ms or to buy household repair materials at a locally owned hardware store rather than at Wal-Mart.

However, political ideology also plays a role in structuring consumer choice in ways that may be less consciously available to consumers and less deterministic in their impact. Consider, for instance, how political ideology might undergird the consumption dilemmas that face a middle-class black family living in or near "ghetto" neighborhoods, that is, predominantly black neighborhoods with high rates of poverty. (We defin the term "ghetto" more precisely else-

*David Crockett is assistant professor of marketing at the Moore School of Business, University of South Carolina, 1701 College Street, Columbia, SC 29208 (dcrockett@moore.sc.edu). Melanie Wallendorf is Eller Professor of Marketing at the Karl Eller Graduate School of Management, University of Arizona, 320 McClelland Hall, Tucson, AZ 85721 (mwallendorf@bpa .arizona.edu). The authors thank the editor, associate editor, and three anonymous reviewers for their assistance with this article. The firs author also thanks the AMA/Sheth Foundation for its grant assistance during the dissertation phase of this research, as well as John Deighton, Don Grant III, Douglas Holt, Sidney J. Levy, Aric Rindfliesch and David Snow for their careful reading and insightful comments on earlier versions of this project. where.) The family may wish to express its ideological commitment to strengthening black community institutions, such as black-owned businesses, through patronage and other forms of support. Yet, when confronted with the clearly inferior product choices typical of ghetto neighborhood stores, this family may opt to shop in (if not migrate to) predominantly white suburbs. Are we to interpret this family's suburban outshopping or outmigration as waning ideological commitment to black community institutions? Perhaps, but political ideology is likely to function in a complex, multilayered, and decidedly nondeterministic manner. It may be consciously available to consumers, or it may be part of an unarticulated structure that nonetheless produces regularities in their preferences. Despite its widespread impact, normative political ideology has received scant attention in consumer research, though notable exceptions (to which we will attend) certainly exist.

This research claims as a foundational premise that political ideology matters in consumer behavior. In this regard, it shares a theoretical platform with an emerging body of research on resistance to the materialist ideology of contemporary Western consumer culture and seeks to extend that research by investigating normative political ideology. The purpose of this article is to investigate the specifi role of normative political ideology in consumer behavior. To this end, we take a critical ethnographic approach to explore the role of political ideology in shaping consumption experiences (e.g., Chin 2001; Peñaloza 1994). While seeking to develop theory that extends beyond this empirical context, we employ as a setting predominantly African-American households in a highly segregated midwestern U.S. city as they confront the problem of attenuated access to goods and services in predominantly black neighborhoods. We begin 
with a review of relevant literature on ideology as well as consumer research. We then present our data and finding and follow with a discussion of the implications of these finding for this demographic group and setting and for consumer research more broadly.

\section{IDEOLOGY}

Ideology is, to say the least, a much contested concept. To paraphrase Eagleton (1991), who specifie some 16 distinct uses of the term, ideology is most properly thought of as a text woven from different conceptual strands with very different histories. It is a complex concept to address theoretically because, unlike the rational logico-deductive approach that dominates contemporary science, some of those strands are incommensurable. While an exhaustive review of ideology as a concept is beyond the scope of this project, it would behoove us to delimit our usage of the term, distinguishing our usage from the myriad ways it has been employed.

In consumer research, the term "ideology" has been most typically employed in a manner largely consistent with Hegelian and Marxist notions of a worldview held by dominant groups. That is, ideology is a system of beliefs and values created and promulgated by a given society's most powerful social group(s). While this narrow definitio overlooks ideology as practiced by nondominant groups, ideology has typically been investigated in contexts where dominant group beliefs and values are used to maintain and legitimate the group's power and control over social relations and social institutions (see Hirschman 1993). The closely related Gramscian concept of hegemony refers to the ability of the dominant group to expand the boundaries of ideology in order to coerce or co-opt consent from subjugated social groups. More recent consumer-oriented investigations have highlighted acts of consumer resistance to the hegemony of Western consumerist ideology, or materialism. Fundamentally grounded in the work of Frankfurt School theorists Horkheimer and Adorno ([1944] 1996), Habermas (1985), and later Bauldrillard (1998), which identify consumer culture itself as an ideological force that induces mass consumer consent and participation in modern capitalism, scholars in this research stream have researched the means through which ideologies structure consumer practices or consumer attempts to counter, resist, or altogether escape consumer culture's confine (see Dobscha and Ozanne 2001; Holt 2002; and Kozinets 2002 for recent examples).

The research presented in this article is premised on a different conceptualization of ideology. It illuminates the role of normative political ideology in shaping the consumer behavior of people making routine choices about where to live and where to engage in household provisioning for basics like food and clothing. In doing so, we seek to broaden the treatment of ideology in consumer research beyond its exclusive focus on consumer culture/materialism and refocus it onto normative political ideology.

\section{Political Ideology}

We begin our investigation of political ideology with a working definitio used in political scientist Michael Dawson's (2001) national survey on political ideology among African Americans. We consciously employ ideology in a manner generally consistent with public opinion and political science research (e.g., Buel 1972), which takes an essentially benign stance toward ideology as a generalized worldview. For our purposes, ideology refers to "a worldview readily found in the population, including sets of ideas and values that cohere, that are used publicly to justify political stances, and that shape and are shaped by society. Further, political ideology helps to defin who are one's friends and enemies, with whom one would form political coalitions, and, furthermore, contains a causal narrative of society and the state. Cognitively, ideology refers to what one 'sees' and responds to in the social world" (Dawson 2001, pp. 4-5).

\section{Black Political Ideology}

Black political ideologies have emerged from a cultural context dominated by American liberal ideology in ways that warrant focused attention in this research. Although emerging from a distinctly oppressive lived experience in the United States, black political ideology must firs be situated within the context of the American liberal ideological tradition more broadly, as this is the crucible in which it is formed. American liberal ideology, perhaps most clearly expressed in The Federalist Papers and in The Constitution of the United States, is characterized primarily by the notion that government should be neutral toward the moral and religious views of its citizens. It should provide a framework of rights and respect individuals as sovereign and capable of choosing their own ends (Sandel 1996, p. 4). Particularly as articulated by Alexander Hamilton in The Federalist $\mathrm{Pa}$ pers, American liberalism is at root an individualistic conception of society that privileges individual over group claims on social resources and prefers a democratically functioning, but weak, central government.

Black political ideologies are thought to make two fundamental departures from the American liberal ideological tradition. First, black political ideologies have directly challenged central tenets of American liberal ideology, historically containing distinct elements of antiliberalism. These include long-standing support for group-based (rather than individual) claims on social resources and an activist (rather than laissez-faire) central government that advocates for social equality. Second, black political ideologies, without exception, have framed racial inequality as a definin experience for black people in the United States (Dawson 2001). By contrast, the American liberal tradition has tended to frame racial inequality as a subset of ethnic conflic more broadly, treating it as a discordant note, even if an historically important one, in an otherwise egalitarian and harmonious political heritage (Omi and Winant 1990).

Given these two significan departures from traditional 
American liberal ideology, in degree if not in kind, we present a brief sketch of the two most prevalent black political ideologies: traditional black liberalism and black nationalism. We present them as ideal types, purposely glossing over considerable nuance within and across these ideological positions in order to provide a starting point for this research.

Traditional Black Liberalism and Disillusioned Liberalism. Traditional black liberalism is the oldest tendency in African-American political thought. Historically, it both informed and was informed by the most radically egalitarian political tradition in American liberal ideology, abolitionism (Foner 1990). While black liberalism has generally mirrored American liberalism, it is also distinct in important ways. Apart from its more explicit approval of group claims on social resources, traditional black liberalism is less apt to trust in the ability of markets to distribute economic and social justice, viewing government as the more appropriate distributive mechanism (Omi and Winant 1990). While traditional black liberalism acknowledges racial inequality as a definin feature of black experience, it remains guardedly hopeful that, with struggle, full integration as citizens in both public and private life will occur.

Traditional black liberalism perhaps reached its historical zenith during the Reconstruction period immediately following the Civil War up to the installation of Rutherford B. Hayes as the nineteenth U.S. president by the Supreme Court in 1877. Traditional black liberalism reached another smaller apex during the civil rights period, sometimes referred to as the Second Reconstruction, during the period from the 1950s to the 1970s (Marable 1991). While proponents of civil rights battled for equal status in legal matters, they also battled for equal status in private market spaces, especially housing, where both law and custom barred blacks from normal market relations (Ownby 1999).

Dawson identifie an additional strand of black liberalism he labels "disillusioned" black liberalism. He identifie it as something of a transitional ideology, in which optimism about the prospects of full integration wanes and turns instead toward garnering resources to the black community. In practice, according to Dawson, disillusioned liberals are likely to eventually gravitate toward ideologies where integration is a less central objective.

Black Nationalism. Black nationalism is the second oldest tendency in black political thought, and it has at certain historical moments been dominant, particularly during periods of intense racial violence and economic downturn. Black nationalism most properly refers to a constellation of fragmented political tendencies that do not neatly cohere. Black nationalist ideology is undergirded by a broad range of conceptualizations of the African diaspora, varying from the notion that blacks constitute "a distinctive people" (i.e., an ethnic group) to the notion that blacks constitute "a nation within a nation." Like black liberalism, black nationalist ideology's historical development is intimately tied to traditional American liberal ideology. However, black nationalism has developed in contradistinction to American liberalism, containing uniquely strong antiliberal elements (Dawson 2001). Black nationalist organizations such as Marcus Garvey's Universal Negro Improvement Association during the 1920s and the Nation of Islam during the ascendancy of Malik Shabazz (Malcolm X) have enjoyed some of the largest bases of membership and support among African Americans (Bennett 1987; Moses 1996).

A common misnomer about black nationalist ideology is that it prescribes strict racial separatism. In fact its tendencies range from implicitly egalitarian forms of ethnic pluralism to outright claims of biological racial superiority. In historical practice, black nationalist organizations have been most likely to advocate for greater community control (i.e., racial control) of local institutions like city councils, school boards, and local businesses in a manner indicative of reform-oriented ethnic pluralism (Omi and Winant 1990). Despite their fragmented character, black nationalist ideological tendencies cohere around two fundamental premises. The firs is that race is the most important - if not sole - category through which black social, political, and economic life is to be conceptualized, analyzed, and addressed. The second premise is that, since whites and blacks in the United States historically have not engaged each other on the basis of social equality, blacks should engage each other in solidarity and exercise some degree of autonomy from whites and white-controlled institutions (see Carmichael and Hamilton 1967). Although what constitutes black solidarity and autonomy from whites varies widely, most black nationalist political expressions, at a minimum, urge the black community to marshal its own resources to generate organic, community-based solutions to social problems.

The liberal-nationalist ideological dyad has dominated black political discourse in the United States from the postbellum era into the present. While they are not outlined in more detail here, other normative political ideologies, namely, Marxism, feminism/Africana womanism, and conservatism, have each seen varying degrees of prominence at particular historical moments, and each significantl shape the contours of ideological debate about inequality in black communities across America. However, black liberalism and nationalism, due to their historical prevalence, constitute the primary normative political ideological categories investigated in this research.

\section{METHOD}

\section{Ethnographic Context}

The setting we have chosen for this investigation is Milwaukee, Wisconsin, a rust belt industrial city of less than 2 million people at the time of data collection. Milwaukee, like most northern industrial cities is characterized by extremely high levels of residential segregation between blacks and whites, giving rise to quite different lived experiences for the two groups (Jargowsky 1997). Few metropolitan areas in the United States experienced as rapid a racialized concentration of poverty, or "ghetto" expansion, as Milwaukee between 1970 and 1990. We employ Jargowsky's 
definitio of ghetto: predominantly black census tracks in extreme poverty (at least $40 \%$ of the residents live below the federal poverty line). We use this income-based defi nition of poverty in order to distinguish ghetto neighborhoods from the area generally known as "Black Milwaukee," the area of highest black residential concentration (Trotter 1985). By 1990, nearly half of the city's black population and nearly two-thirds of its black poor lived in the more than 50 census tract neighborhoods that by then had come to form the ghetto, all percentages that had more than doubled since 1970 (Jargowsky 1997). Black Milwaukee is home to the city's highest concentration of neighborhood poverty, and the Milwaukee metropolitan area displays the pattern of black population dispersion characteristic of highly segregated cities. Sociological literature on the impact of this kind of residential apartheid is clear. High levels of residential segregation imply restrictions on the opportunities and resources available to African Americans, even those living in suburbs, when compared to whites of similar social status (see MacLeod [1987] 1995; Massey and Denton 1993; Shapiro 2004). This rapid expansion of poverty concentrated inside virtually all black neighborhoods, particularly since 1980, makes Black Milwaukee the epicenter of both race and class inequality in the setting.

\section{Research Team}

Since race and gender have such wide ranging impacts on social interaction (Collins 1988), particularly on researcher-informant interactions (see Davis, Gardner, and Gardner 1941; Griffi 1961), it is worth noting the composition of the authorial team. The firs author, a black male, conducted all of the fieldwork as is appropriate in dissertation-based research, for a 10-mo. period during 1998 and 1999. While his race privileges his access to discussions of race with other blacks, it likely suppressed such discussions with white informants. Further, because household provisioning is a predominantly female activity (DeVault 1991), his gender required him to develop sufficien rapport with informants of both races to overcome this difference. The second author, a white female, provided analytical distance in both data coding and analysis.

\section{Sample and Procedures}

In order to provide variation on characteristics of interest, informants were selected for variation in race, socioeconomic status, and neighborhood racial composition, as shown in table A1 in the appendix. Neighborhood racial composition is employed here as a rough indicator of a neighborhood's location inside or outside Black Milwaukee rather than as an indicator of residential exposure to racial others per se. In addition to these informants, from whom interview and observational data was collected, the firs author maintained contact with a number of key informants from local institutions. These institutional informants, listed in table A2 of the appendix, were helpful in providing deeper access to community-based organizations, cross-checking data derived from interviews with informants, and helping the researcher gain an understanding of the broader dynamics of race, class, and gender in the city.

\section{ATTENUATED ACCESS TO GOODS AND SERVICES IN BLACK MILWAUKEE}

It is virtually taken for granted by informants of all races that attenuated access to a variety of goods and services in Milwaukee's largely black and Hispanic neighborhoods is an ongoing social problem; that is, people who shop in these neighborhoods, regardless of their socioeconomic status, do so at a marked disadvantage when compared to people shopping in other neighborhoods in the same metropolitan area. The most extensive secondary data available in this setting are on food purchased through traditional retail channels (primarily grocery stores and other nonemergency retail food outlets). Extant reearch asserts that consumers in black and Hispanic Milwaukee will typically face higher prices and a smaller selection of products than will a person shopping outside these areas. The authors attribute this to the fact that large food stores (between 100 and 249 employees), in all but one instance, are distributed away from these sections of Milwaukee County (Johnson, Percy, and Wagner 1996). In fact, during the period of data collection for this article, plans to build a large grocery store in the heart of Black Milwaukee made front page news in the city's major daily precisely because of the lack of such stores in the area (Daykin 1999). Large stores are important retailers because they purchase in bulk, often resulting in purchase price discounts that can be passed along to the consumer. When arrayed solely by store size, identical baskets of food purchased from large food stores in Milwaukee County cost $24 \%$ less than in the county's smallest stores (Johnson, Percy, and Wagner 1996). By contrast, small (between 5 and 19 employees) and micro-sized (4 or fewer employees) stores constitute over $90 \%$ of the food retail outlets in black and Hispanic sections of Milwaukee County. These stores typically offer fewer products, few if any unbranded (generic) products, and fewer items available at reduced cost than large- and medium-sized food retail outlets (Kaufman and Lutz 1997). Only infrequently do microsized stores have scanners that would include their customers' purchases in scanner panel data sets. Overall, the relative absence of large stores and the high concentration of small stores in innercity areas mirror finding from similar studies done in other metropolitan areas (e.g., Bell and Burlin 1993).

This uneven distribution of stores simultaneously concentrates the lowest-cost retailers with the best food selection outside of Black Milwaukee and the highest-cost retailers with the worst food selection inside of Black Milwaukee. Additional observation by the firs author in stores across the metropolitan area supports the Johnson, Percy, and Wagner (1996) finding that small stores and micro-stores carry a much more limited range of products and brands than medium or large stores in every section of the metropolitan area. This range typically excludes or 
sharply reduces the availability of generics and private-label brands. Observation in the setting also reveals that shoppers face related disadvantages in accessing a wide array of market-derived goods and services, including housing, banking and financia services, clothing, home improvement goods, and pharmacies, as well as public and semipublic goods like quality schools and nonemergency medical services.

\section{Exit, Loyalty, and Voice Responses to Attenuated Access}

The relationship between rapidly concentrating poverty, racial residential segregation, and the uneven distribution of retail stores in attenuating access to goods and services in Black Milwaukee is symbiotic. It is historically tied to basic shopping patterns in the metropolitan area and to the development of suburban housing. Yet the problem of attenuated access to goods and services cannot be pinned solely on structural factors like segregation, concentrated poverty, or discrimination by service providers. Such reductionism glosses over the agency of actors in framing and responding to their consumption dilemmas. Consequently, we move beyond noting the pervasiveness of attenuated access to goods and services by analyzing consumer responses to this ongoing social problem.

We employ Albert Hirschman's (1970) exit, loyalty, and voice (ELV) framework as a typology of consumer responses to attenuated access (see table 1). Typologizing has been used in sociological research as a conceptual tool by which the subsets in some empirical domain are ordered and classifie by their similarities and differences. "The resulting classificato y scheme directs the observer's attention to certain aspects of the phenomenon under study" (Snow and Anderson 1993, p. 37). The ELV framework has been employed across a wide array of contexts, at both the organizational and individual levels, ranging from individual responses to interpersonal relationship dynamics, dissatisfaction in employment, and dissatisfaction with service encounters, to the formation of splinter organizations (see Withey and Cooper 1989 for a review). Exit refers to actually leaving (or at least thinking about leaving) an organization, relationship, or setting. Loyalty involves giving public or private support to an organization, relationship, or setting, typically including optimism about the prospects for improvement. Voice includes active and constructive attempts to improve conditions through expressions of one's opinion and perspective with others. It may involve complaining about prevalent conditions or constructing and articulating a causal explanation and/or critique of prevalent conditions.

We employ the ELV typology to focus our analysis on sociological aspects of consumer responses to attenuated access to goods and services. That is, we wish to direct attention to consumer responses to attenuated access and their impact on social relations in the setting. While the vast extant literature on coping might also serve as a framework that would generate useful insight, coping research has traditionally focused attention on cognitive repositioning and/ or individual behavioral adaptations to consumption dilemmas, rather than their sociological outcomes (e.g., Mick and Fournier 1998). We use the ELV typology as a tool for theorizing about the sometimes conflictua social relations expressed through household provisioning behavior. Consequently, what motivates this analysis is an attempt to understand how social relations come to be constructed and legitimated through shopping in a setting characterized by attenuated access. Just as Daniel Miller's (1998) analysis of provisioning in North London underscores love as an ideological force that legitimates relationships between the provisioner and other members of the household, we explore normative political ideology's role in legitimating, and in part constructing, social relationships between households and neighborhoods in the setting.

We use the ELV typology to group individual responses to attenuated access into broader categories of action, while still capturing the basic array of responses structurally available to consumers. As informants articulate their exit, voice, and loyalty responses to attenuated access problems, they reveal whom they have framed as political allies and political adversaries. They also provide a causal narrative about attenuated access and its role in their household's relationship to the black community and to the broader community outside Black Milwaukee.

\section{Black Liberal Ideology: Responses to Attenuated Access}

Our research find several responses to attenuated access to consumer goods and services in Black Milwaukee that emerge from black liberal political ideology. Of course, ideology is not so deterministic as to produce the same response

TABLE 1

CONSUMER RESPONSES TO ATTENUATED ACCESS TO FOOD IN BLACK MILWAUKEE

\begin{tabular}{lcc}
\hline \hline Normative political ideology & Exit & Response type \\
\cline { 2 - 3 } $\begin{array}{c}\text { Traditional black liberalism and } \\
\text { disillusioned liberalism }\end{array}$ & $\begin{array}{c}\text { Outmigration, outshopping } \\
\text { Black nationalism }\end{array}$ & $\begin{array}{c}\text { Neighborhood preference } \\
\text { Outshopping, opposition } \\
\text { to outmigration }\end{array}$ \\
\hline
\end{tabular}


in all consumers all of the time. Nonetheless, black liberalism tends to generate these basic responses to attenuated access: outmigration and outshopping, neighborhood preference, and critiques of black working-class consumer behavior. Responses that emerge from black liberal ideological forms tend to revere consumer sovereignty in the form of unbridled consumer choice, identifying it as the definin feature of normal and desirable market relations. Liberal ideologues in our sample construct a causal narrative about attenuated access that emphasizes dysfunctional choices on the part of some consumers in Black Milwaukee and the role they play in erecting barriers to entry for all but the least desirable retailers. Black liberal ideologues tend to privilege responses to attenuated access problems that are designed to expand the set of alternatives available to their households.

Exit Responses. For some traditional black liberal consumers faced with the problem of attenuated access to resources, resolution seems simple and clear: either stay away from Black Milwaukee or exit it. That is, the most apparent exit response is to migrate to a setting endowed with better resources, a strategy referred to by sociologists as outmigration (e.g., Wilson 1987). It constitutes the strongest form of exit response available to consumers.

The dilemma of where to live within a metropolitan area is a consumption decision with far-reaching social, economic, and lifestyle consequences, both for those making the choice and for their neighbors. It is a decision that is intricately associated with race, both one's own and that of the others with whom one will mix. For sufficientl enabled black consumers, crossing racial boundaries to move to predominantly white areas is often an economically rational exercise of residential choice. However outmigration is also a political act that has its difficultie because it defie extant racial norms that identify blacks as the least desirable neighbors, regardless of their income (Charles 2001). This difficult is expressed by Anne, an upper-middle-class black female who lives in a white neighborhood, when asked about her decision to locate there.

That's how I see it. You know nobody's telling me where I can live - not if I got the money and I want to live there.

Like many, if not most, American homebuyers, Anne, who lives with her husband and two school-age children in a predominantly white section of Milwaukee, cites school quality as the deciding factor in neighborhood choice. Many Americans, particularly the middle and upper-middle classes, see quality schooling as an essential element of economic advancement. Yet, for blacks in the United States, this economic rationale for neighborhood choice must be accompanied by a traditional American liberal political stance toward residential integration with whites, as the best schools are rarely located in predominantly black sections of metropolitan areas. Anne and her husband Eric were the firs black family to settle on their block. Anne explains:

So to me, that's like a big thing for me-is the school. And Eric [Anne's husband] didn't want us to do private, so I'm going where the best schools are. And if that's where the white folks go, that's where we're going.

Consistent with traditional black liberal ideology, Anne envisions residential outmigration as a response to a general attenuation in access to resources faced by blacks in segregated cities. For this couple the articulated goal of outmigration is to give their children the advantages associated with an education on par with others of similar means.

In traditional black liberal ideology, as in all liberal ideological forms, sovereignty, often expressed as the free exercise of choice between available alternatives, is central to its construction of social relations. The following data excerpt articulates the logic behind Anne's residential choice and reveals her construction of allies and adversaries. The resistance she expected from white neighbors when her family moved into the neighborhood is exemplifie by a woman who refused to speak, despite repeated overtures, for their firs 5 yr. in the neighborhood:

So I could tell she couldn't handle it. She just never spoke. The thing that made me feel good is that after fiv years she did. She finall did start coming around. It took her a while, but that's OK because that's what she grew up with and that's what she's used to. That's OK. The fact that she did [eventually speak] means there's hope. If somebody that old who is so set in their ways can turn around-and in this past year she even invited us over.

The neighbor's initial unfriendliness is on some level unexceptional. Sociologists and historians fin that the firs black residents in previously all-white settings are frequently made to feel as unwelcome visitors, if they are not exposed to outright harassment (see Feagin and Sikes 1994). What is critical to this discussion is how Anne's response embodies the essence of traditional black liberal political ideology. She expects her residential choice to be problematized by negative attitudes from whites, but she remains determined to make meaningful integration possible through the strength of her family's resolve. In retelling the story, Anne introduces her neighbor's intransigent negative attitude with a smirk that belies her annoyance with this woman. By the end of the tale, however, she is able to dismiss the attitude as an unfortunate vestige of "the old days," one eventually conquered by her family's determination not to be undone by it. From her initial construction of the neighbor as an adversary - one who resists her residential choice-Anne can ultimately construct this woman as an ally-one who accepts her choice and reciprocates her overtures of hospitality, without having to change her own liberal ideological position. 
Negative attitude and shunning from a white neighbor, however, is not the sole source of opposition to Anne's residential choice. She is particularly frustrated about the deep-seeded and long-standing conflic surrounding the role of middle-class outmigration as a response to resource deprivation in black communities. Anne responds to a probe about opposition from blacks to her family's residential choice:

Researcher: Have you run into that [negative attitudes from blacks about living in a white area]?

Anne: Oh, man, I feel like this is probably one of the most segregated areas I have ever lived in. And a lot of the segregation comes because the black people have this mind set that they gotta stay in [a] certain area. That they can't-you know we're beating up on somebody who chooses to live where they want to live. You know if I said it's OK for you to live in the city, don't tell me it's not OK for me to live where I want to live.

Unlike with her elderly white neighbor, whose negative attitudes she can dismiss as an historic relic, Anne struggles to understand how other blacks can criticize her residential choice in this way. Further, she is pained that she must come to construct other blacks as foes. Blacks, she feels, should especially value freedom of residential choice, if for no other reason than the struggle to obtain it has been so costly. Fair housing legislation was the last victory of the civil rights era and perhaps the most bitterly contested at the national level (Massey and Denton 1993). For blacks to impose ingroup social sanction on the free exercise of those hard-won rights seems to her, as a black liberal, anathema to the struggle that gave them birth.

Whether a lack of financia resources makes outmigration a precarious response or the prospects of facing discrimination make it undesirable, continuing high levels of blackwhite segregation suggest that residential outmigration to predominantly white areas is not a strategy successfully pursued by many blacks in Milwaukee.

Another exit response to attenuated access that is fundamentally similar to outmigration is outshopping, or leaving one's residential area to acquire needed goods and services. This is a qualitatively weaker response to attenuated access than is outmigration. However, it is widely available and widely employed by consumers. Florine, who is a middle-class black female who lives in a black neighborhood on the northern fringe of Black Milwaukee, shops outside her neighborhood. She cites safety and convenience as the reasons she shops at the large grocery store close to where she works (in a predominantly white area). This is not surprising as the closest medium-sized grocery stores to her to home are also in an adjoining white neighborhood. A closer inspection of her comments, however, reveals a feature of traditional black liberal ideology that distinguishes it from the broader American liberal tradition, namely, the strength of its preference for racially integrated, upscale settings.
Researcher: What is it about their atmosphere [referring to stores in white areas]?

Florine: Good question. I don't know. I hate to say this. I don't want to sound-

Researcher: [after pause] Oh, just say it.

Florine: But I just-I feel-to me the clientele is better [at the predominantly white area store]. You have more-it looks like more middle-class [patrons]-I don't want to seem like [I'm] prejudiced, because I'm not that way. Believe me, I've been both [working and middle class]. It's not that. It's just, I just feel safer. It seems to be more security around the area. The parking is closer into the building. What can I say?

Researcher: So you don't fin the atmosphere to be as objectionable at [the white-area store] as opposed to the other one?

Florine: For different reasons, different reasons. Now when I mentioned about the other [Black Milwaukee store] it was mainly because of atmosphere and maybe service. This one over here, you may have the atmosphere and the service, but your attitudes are different.

Researcher: How so?

Florine: When you even ask for directions, like where are certain items in this aisle? May I have this? Can you help me with this? They don't seem to be as ready to help you, to assist you as quickly, and I'm very sensitive to that, and I guess a lot of blacks are when you've been rejected and you have to deal with racism in certain areas whether subtle, or overt, whatever. And I pick up on stuff like that.

Researcher: So you're saying that having to shop at-when you do decide to shop at a store on this side of town, the [predominantly white] south side, basically, that you're much more sensitive to racial prejudice?

Florine: Yes. I'm very aware, and that should not be, and it's not my imagination. It's real. And I've seen the books to know, and I pick up attitudes enough to know. Especially being in a school and being in an area for so many years where it wasn't even pretend racism, it was just open racism and prejudice. You are very sensitive to that. So I guess, even asking directions in a store, I overhear sometimes. The only reason I stop there is out of convenience, and they do have the service available. But you can tell by the responses to your questions, things like that—and it's almost like, "You don't go _ " "You don't_-" "Who are you?" And "Don't let you walk in with your head held high like you own the place." Some of them really get upset.

During her childhood, Florine's family was a prominent activist family in the city. Her father, a minister, tried unsuccessfully to integrate several of Milwaukee's all-white residential neighborhoods in the 1950s. She and her brother were among the firs students to integrate a previously allwhite high school in the city as teenagers. That experience, one of obvious political and social significance was also 
one marred by social isolation and racial violence. Yet the continuing significanc of social integration as a personal, political, and economic goal is revealed in how she frames her store choice. Florine's concerns about safety and product quality echo those found often among informants who patronize Black Milwaukee's stores. However, Florine regularly patronizes a store where she is made to feel as if she is receiving diminished service, if not entirely unwelcome. She has framed this provisioning choice as one where she would rather confront perceived discrimination and diminished service for superior product than perceived safety issues for inferior product. She has also framed her store choice as one where she is challenging an implicit taboo by patronizing white-area stores. This instance from the data reveals that the promise of better product at lower prices in a presumably safer environment is not the sole function of outshopping. An additional, latent function of this exit strategy is to allow her to obtain a perceived prestige closely associated with racially integrated and socially exclusive settings long denied to blacks. Scholars have long noted that the status value blacks associate with integrated social settings stands apart from their purely utilitarian value (e.g., Drake and Cayton 1945; Frazier 1957).

In contrast to Florine, some informants respond to attenuated access by choosing to do a significan percentage-if not all —of their provisioning inside Black Milwaukee's ostensible boundaries. These are labeled loyalty responses. However, for each of these informants, because stores in Black Milwaukee remain such a dominated price, quality, and selection alternative, their loyalty remains a significan source of conflict

Loyalty Responses. At the household level, outshopping is the most effective economic response to attenuated access to food in Black Milwaukee. However, exit responses like outshopping come with some cost, and the set of resources necessary to access white-area stores are only infrequently available to some. Consequently, many patronize the limited number of medium-sized and small stores in Black Milwaukee, making the quintessential trade-offs between price, quality, and convenience identifie in prior neoclassical research (e.g., Haines, Simon, and Alexis 1971). For many black outmigrants, remaining loyal to Black Milwaukee's institutions constitutes a way of maintaining ties to black community life. Pat, a middle-class black female who lives in a white neighborhood, is a committed and active parishioner at a church in the heart of Black Milwaukee, where this interview was conducted. Pat attends multiple weekly meetings despite a lengthy commute from another area of the city. Despite her commitment, Pat - who is not a native Milwaukeean - continues to feel like a somewhat disconnected outsider at times, and thus she employs provisioning to help her create and sustain feelings of connectedness.

Researcher: Give me some of your impressions.

Pat: Of Milwaukee? To me it's a very closed community.

Researcher: In what way?
Pat: In the sense of it's kind of . . . if you didn't grow up with folks here, it's kind of hard to be a part of things. . . . But as a community - I don't see the community, really.

The very difficul work of household provisioning has ideological as well as utilitarian aspects, though its ideological underpinnings often remain below the surface. Pat's loyalty to black community food retailers, despite her somewhat ambivalent relationship to Black Milwaukee, is predicated on a rational weighting of taste, product availability, convenience, and price. It originates with her inability to acquire certain goods at the stores in her predominantly white neighborhood without paying a premium:

Since I stay on the south end, and that's predominately - the community I'm in is Russian and German descendants-a lot of stuff I'm not going to fin down there. I'll have to drive. I have a vegetable market down there [in the predominantly white area] that when I want greens they said if I give them a couple days notice, they'll come here [to Black Milwaukee] and get it for me. So while I wasn't [working in] the city I would use them, they would charge me about $10 \notin$ more per pound for the greens than if I just-I came here. But when I want them, I'm willing to pay that $10 \varnothing$ more a pound. Now I get them on the way home. And if I want to go to the fis market to get some fried catfis and stuff, I drive up here to the Center Street fis market and get some fried fis because they don't have fried catfis down there.

Her loyalty is, in this sense, strictly neoclassical, but it is not simply that. Pat's loyalty must also be understood normatively as one feature of her overall support for community institutions in Black Milwaukee, particularly her church. She spends between 5 and 7 evenings each week actively engaged in various church committees and functions.

Researcher: I'm interested in understanding what you think, in general, inside a community, what the role of a church should be.

Pat: I think the role of the church has so many facets. Inside the community, I really think the church is the place where the people come to be equipped to handle the work that needs to be done around community.

The firs author accompanied Pat as she patronized blackowned grocery stores in Black Milwaukee. There she articulated the importance of supporting such institutions, despite her disappointment in their assortment and the quality of goods generally available. While in her kitchen, as she instructed on the proper methods of preparing catfish greens, and cornbread, it became apparent to the researcher that Pat's patronage of Black Milwaukee's stores functioned to provide her with an additional taste of black community life - an opportunity to connect with an aspect of community life that can be consumed and shared with others. Just as other scholars have noted the connection between community and food (Harris 1985; Oswald 1999; Wallendorf 
and Arnould 1991), we note that Pat's loyalty to Black Milwaukee's stores signifie her loyalty to the broader black community despite her residential and interpersonal distance from it.

Voice Responses. In this setting, "voice" responses are likely to take the form of a causal narrative that expresses an informant's situated understanding of attenuated access to consumer goods and services. This is somewhat counterintuitive to the literature, as voice responses typically include some form of complaining to the management of substandard stores. On the contrary, informants in this sample rarely spoke of complaining, even in the face of extreme dissatisfaction. Informants who spoke of either seeing or purchasing food at retail that had spoiled were likely to exit the store rather than complain.

Rather, informants in this sample articulate causal narratives that reveal an emic understanding of attenuated access in Milwaukee as the wholly foreseeable, if not inevitable result of antagonistic relations between segments of Black Milwaukee and those who serve it. In this excerpt from the data, Eric, an upper-middle-class black male who lives in a white neighborhood, joins his wife Anne in describing the loss of retail in Black Milwaukee as a function of consumer inactivity. He suggests that low levels of consumer spending (rather than crime) in Black Milwaukee have failed to yield sufficien revenues for retailers, in effect pushing them away to white neighborhoods.

Eric: The other thing that - not speaking against any income levels here-just shows you that people don't spend. I've seen stores - major chains - close in the areas that aren't run down. I've seen a Burger King up on [the northern boundary of Black Milwaukee] that has closed-opened and closed three times since we've been here. In that same region a Pizza Hut closed, a Marshall's closed, right by the mall. Other parts of town I've seen Taco Bells close. It's people here just don't have the income. Or the people that do spend, they're not spending enough to keep these major establishments in business. So you have, on certain parts of town, you have just a lack of retail whereas it's concentrated in two places here: basically on the [predominantly white] south side by Southridge [mall], or the west side by where all the uppermiddle-class white folks live . . . Northridge Mall [on the northern boundary of Black Milwaukee] is a ghost town in terms of the normal consumer. It's a bunch of kids out there that are walking around in the mall. But they're not spending money, or the things they're spending money on are probably sneakers. Again I'm generalizing, but that's basically what it is, and that's why you see these major chains closing. And even down in the center city, like Capital Court Mall. How many places do you know where a Target has closed? Target just closed. There weren't enough people shopping-

Anne: There was a killing too.

Eric: That's part of it, but isn't a run-down mall per se, it's not in a high-income area. But it's not straight ghetto. It's got a lot of homes in the area and stuff, but there's just not a consumer base to support it.

Eric believes that Milwaukee generally is steeped in an excessively thrifty, working-class local culture that lacks a certain cosmopolitanism and taste for the fine things. He and his wife often lament the paucity of retail offerings relative to similar-sized cities in the southwest. His point is that the excessive thrift prevalent in local culture ultimately drives business toward areas with higher disposable income, and a willingness to spend, in the suburbs. Eric is making a claim that store closings in predominantly black areas are only partly a function of low average incomes. Capital Court Mall, a mall berated by other informants for its poor-quality stores, is not "straight ghetto," meaning that the mall is not situated in the most destitute and crime ridden of Black Milwaukee's neighborhoods. Rather, according to Eric, consumers who are able to spend are choosing not to spend enough to keep businesses sufficientl profitable Retail abandonment of Black Milwaukee is the natural consequence. Thus Eric aims a class-oriented critique at Black Milwaukee's mostly working-class inhabitants that admonishes them for being insufficientl acquisitive to retain local business. Of course, central to his narrative is the role of choice, but in this instance he references the dysfunctional choices of others. In his narrative, attenuated access is constructed as the foreseeable outcome of consumer decisions about when and where to spend money.

\section{Black Nationalist Ideology: Responses to Attenuated Access}

In contrast to the logics behind the responses of black liberals, responses to attenuated access that emerge from black nationalist ideology include opposition to outmigration and outshopping, entrepreneurship, critiques of black criminality and racist assumptions, and racial chauvinism. These responses, rather than privileging individual sovereignty, problematize it to varying degrees. Nationalist responses are oriented around gathering resources to Black Milwaukee to improve it.

Exit Responses. Liz Carter (an upper middle class black female who lives in a black neighborhood), despite her wish to support Black Milwaukee's businesses, refuses to patronize the small and medium-sized grocery stores in her predominantly black neighborhood for anything but lastminute fill-i purchases of nonperishables. She does the bulk of her provisioning at larger stores located in predominantly white areas. Her decision to shop - but not live-in white areas suggests an underlying ideological conflict When it comes to provisioning, she is motivated to seek out the bestquality product at the lowest cost. Thus she clips coupons, searches for sales, and literally shops all over the metropolitan area. However, rather than extend this logic to her residence and relocate to an area with substantially better resources, she chooses to remain in Black Milwaukee despite its aforementioned challenges. 
Researcher: Where do you acquire most of your food?

Liz: All over town. We shop where the best deals are.

Researcher: Have you considered relocating to the suburbs?

Liz: Sure, we could move out to the suburbs. We could have moved out there years ago. But what kind of message does that send our kids? That we gotta go where the white folks are to have nice things?

Liz's comments raise two basic concerns about outmigration to predominantly white areas. First, as suggested in her comment, outmigration sends the message that predominantly black neighborhoods are not desirable places to live. As Harris (1999) and Charles (2001) compellingly find this negative association with black neighborhoods readily extends to blacks as neighbors, as their presence is unambiguously associated with encroaching neighborhood decline. Liz's second implicit concern, echoed by sociologist William Julius Wilson $(1987,1996)$, is that significan black middle-class outmigration to predominantly white suburbs results in economic (and social) capital fligh from predominantly black areas. Wilson asserts that, as increasing numbers of middle-class and stable working-class black families leave predominantly black neighborhoods for presumably greener suburban pastures, they remove sorely needed tax revenue, entrepreneurial skill, and disposable income.

Liz's coupling of outshopping with opposition to outmigration reveals her ongoing ideological transition from disillusioned black liberalism to community-based black nationalism as the basis for her provisioning behavior. Outshopping is a milder and more politically palatable form of exit than outmigration for informants who articulate a black nationalist sensibility but who remain faced with a dominated shopping alternative in Black Milwaukee. Dawson (2001) identifie disillusioned liberalism as a strand of black liberalism that retains its traditional emphasis on sovereignty but takes a critical stance toward social integration with whites as feasible or appropriate. He identifie community-based nationalism as an ethnicity-centered strand of black nationalism; that is, the basis of black ethnicity inside the United States lies in dynamic black population centers in inner cities. Communitybased nationalism exhorts members of the black community to look inward, garnering community-generated resources to meet community needs. Unlike some forms of black cultural nationalism, community-based black nationalism does not eschew social, political, and economic contact with whites per se. In practice, community-based nationalism recognizes the impracticality (if not impossibility) of withdrawal from institutions dominated by whites. It does, however, problematize residential integration with whites as an appropriate response to attenuated access to resources. In doing so, communitybased nationalist ideology renders the free exercise of residential choice favored by Anne (upper middle class/black female/white neighborhood) problematic in explicitly antiliberal terms. In its most pristine form, it views outmigration or outshopping in white areas as antagonistic to the black community because it funnels resources toward other areas.
Thus, for Liz, at the time of data collection, an inherent tension exists. Liz is unquestionably devoted to her household, but she is also explicitly devoted to Black Milwaukee. She sees it in severe economic and social decline and believes that the city's black community must marshal its collective economic, social, and political resources and administer them to solve its myriad social problems. In fact, her devotion to Black Milwaukee has negatively affected household wealth directly because her house has never appreciated in value, while a similarly priced home purchased in the suburbs at any subsequent point would certainly have done so. Liz, of course, places limits on the degree to which she will subordinate her family's interests to her devotion to Black Milwaukee. In truth, she does not frame them as oppositional or in zero-sum terms. It is precisely because of her devotion to her children's cultural and psychological development that she remains in Black Milwaukee, hopeful that its unique cultural and kinship bonds will not continue to be overwhelmed by persistent social malady. Yet, as her underlying political ideology transitions to communitybased nationalism, she find that its fundamental premise of "in-group solidarity/out-group autonomy" serves as a basis for interrogating individual- or household-level choices, and it can render such choices problematic.

Loyalty Responses. Black entrepreneurship is a loyalty-based response to attenuated access that is historically steeped in the discourse of the most politically conservative black nationalist tendencies. As a tactical response to Jim Crow laws, which barred blacks from normal market relations, black entrepreneurship rose to prominence with Booker T. Washington's infamous speech at the Atlanta Exposition in 1895 (Bennett 1987). Washington's speech, counseling separation in social matters but unity in economic matters, articulated a broader strategy of accommodation to racial terror by ostensibly sacrificin civil rights for economic advancement. As Cha-Jua and Lang (1997, p. 1) note, "In suitably accommodating, but dissimulating language acceptable to the agrarian barons in the South, the emerging Northern industrial capitalist elite, and an evolving Southern-based conservative black elite, Washington announced the shift in African-American strategy and tactics 'from politics to economics, from protest to self-help, and from rights to responsibilities." While not considered by many scholars a nationalist himself, Washington's vision of entrepreneurship has profoundly influence nationalist thinking. Marcus Garvey, who emigrated to the United States specificall to meet and study under Washington, urged the development of a parallel black economy. More recently, the Million Man March catapulted black entrepreneurship back to prominence, where it remains a central tenet of black nationalist strategy for the social and economic development of black America (Cha-Jua and Lang 1997).

Embodying this ideological position, Tim, who is a black, middle-class, business owner, frames his farm stand cooperative as a response to demand for fresh produce and a vehicle for economic development in Black Milwaukee. 
We now have 10 farmer's markets in the city. One of the things I've been doing . . . is developing farmer's markets in strategic areas of the city because of the lack of grocery stores. . . . It does two things - it provides food to the consumers, and, to some degree, job security. It helps the small family farmers by providing an outlet for their produce. . . . We could use a market on the far west side of the city because we've got a lot of folks there in this northern area, people that move from the central city - a lot of low-income folks - that could use fresh produce.

While Tim is not a consumer speaking of his own shopping strategies, his response to attenuated access is nonetheless critical to this analysis. His entrepreneurial response illustrates a well-developed community-based nationalist ideology. In traditional liberal ideology, actors have historically emphasized migration to settings with the best resource endowments as a means of expanding their available choice set. Tim, however, emphasizes entrepreneurial activity aimed at garnering resources to Black Milwaukee. He envisions the farm stands, organized as producer co-operatives, as a source of community economic development, rather than solely as a personal revenue-generating enterprise. To underscore the economic justificatio for this ideological supposition, he cites a noted black conservative syndicated columnist, William Raspberry, to suggest that U.S. central cities are underserved relative to their buying power.

I was reading an article by William Raspberry. You know William Raspberry - a writer for the Washington Post? He said the income in the central cities in this country is more than the economy in Mexico. There is tremendous buying power in the central cities. It is just a matter of who wants to go in there with the right attitude and build stores.

While it is quite unlikely that Tim would compare himself favorably with black conservative ideologues in many respects, he nonetheless articulates an essentially similar understanding of the black community undergirded by nationalist ideology. Namely, it has a collective racial self-identity that is distinct from the locale in which it is situated, and it has a sizable store of social and economic resources that could be devoted to solving its myriad social problems. He accepts Raspberry's (and essentially Washington's) presupposition that "central cities" are sufficientl economically distinct from the metropolitan areas in which they are situated that their cumulative economies can be aggregated and favorably compared to those of sovereign nations.

In a strictly behavioral sense, loyalty responses by both liberals and nationalists are fundamentally similar in that they both stress support for local business. However, critical ideological distinctions emerge. For liberals, their articulated preference for Black Milwaukee's stores is framed as the outcome of a choice between weighted available alternatives. So, for Pat (middle class/black female/white neighborhood), a traditional black liberal, supporting black-owned businesses is part of a broader ethic of civic involvement in Black Milwaukee, but that support is clearly bounded by price, quality, and cost concerns. Alternatively, Tim, a rational business owner, not surprisingly, sees Black Milwaukee as an underserved market but not one to exploit for personal gain. His entrepreneurial response is expressed in political terms, as the centerpiece of a broad, community self-improvement strategy that includes job development, community gardening, and greenhouse farming education programs targeted at children.

Absent from our informants' accounts is an expressly stated preference for patronizing black-owned stores rooted in black nationalist political thinking. Researchers have noted at least the symbolic significanc of black-owned businesses in predominantly black areas (e.g., Chin 2001; Lee 2002). On this basis alone, one might suspect that Black Milwaukee would be rife for appeals to racial group and neighborhood loyalty. Yet, to the extent that preferences for neighborhood stores appear at all in informant accounts, they are based on carefully considered criteria related to specifi offerings rather than to appeals to race pride or community economic development. In fact, only a few entrepreneurs in Black Milwaukee made symbolic appeals to black business ownership. For instance, one microsized store, selling mostly candy and soda, displayed an outline of the African continent on its outdoor sign. Another variety store featured a graffiti-styl mural on the side of the building that caricatured the two black store owners. Generally, though, such displays by businesses were rare, as was a racial solidarity basis for loyalty among residents in the setting. One explanation for the absence of this particular expression of nationalism on the part of consumers is that, historically, appeals to support black-owned business have been most successful when they have been part of broader campaigns to battle racial inequality and discrimination in the marketplace and employment. "Buy Black!" and "Don't Buy Where You Can't Work" were common appeals of an earlier era that revealed popular sensibility about the existence of Jim Crow laws and customs prevalent in market spaces until the latter third of the twentieth century (Marable 1991).

Voice Responses. Voice responses to attenuated access that emerge from black nationalist ideology involve primarily causal narratives about attenuated access and critiques aimed at those thought responsible. One group whose behavior is widely thought to be a cause of retail abandonment in Black Milwaukee is its working-class and poor youth. Elijah Anderson (1999) highlights the tension between the competing "norms of decency" and "the code of the street" in inner-city life. Liz (middle class/black female/ black neighborhood), a social services provider for families and youth, mother of two teenagers, and wife of a whitecollar executive, in every respect embodies prevalent social norms of hard work and decency. Yet, despite her personal adherence to such norms, she lives in a neighborhood where they are directly contested by crime and violence and which is clearly in the throes of economic decline. During an interview, she documented a list of houses on her block and 
the next where she claims illicit drugs are sold. The drug trade and its associated violence are the factors leading most directly to her neighborhood's decline. In addition, in her assessment, petty theft and the threat of violence from black youth are the primary factors leading to retail abandonment of the area. They lower the bottom line for retailers by raising costs and driving away potential customers. She attributes store closings directly to the black working-class and poor youth most likely to be involved in shoplifting and loitering in Black Milwaukee's stores. While Liz is also critical of managers, particularly those in unkempt, lowquality stores, she places the onus for store closings squarely on black poor and working-class youth.

There had been a Boston Store there [at Capital Court Mall]. A Marshall Field's, Target. . . I think. . . . Well, with many of the stores, once students were able to go visit the mall during the course of the school day-and many of them go there with the intention of stealing - the stores just had to go. I mean, there was a lot of stealing going on, and kids, when they go to the malls, they really don't know how to act, many of them. They are there to run around or play their music loud, or harass people, and they just can't continue to do that. . . . Many stores are not renewing their leases because unfortunately when we go someplace we don't always act right. We just put on a show, to some extent. . . . They don't need to go and steal. There is no excuse for that. There really isn't. There are a lot of opportunities for jobs. Many of the high school kids can get jobs from different programs that the counselors have available to them, but they want a top-shelf job you know, making $\$ 14, \$ 15, \$ 16$ per hour. They don't want to start small and work up, you know. They want to be able to set their own hours.

Liz laments that the challenges of doing business in Black Milwaukee have become too great for many retailers due to the crime and violence perpetrated by the black youth who inhabit the area. In shifting between the third-person and first-perso plural pronouns "they" and "we," she alternately critiques the actions of these youth and takes personal responsibility for their consequences. What underlies her conceptualization of black youth crime is a black nationalist rendering of decidedly liberal political ideology on black culture of poverty (or black cultural deficiency) Liz notes,

We can always say it is economics as to why we deal drugs, as to why we steal, as to why we jump from place to place, but I don't buy it all the time. For some of the families that I interact with, yes it could be that. But for some of the students that I have to go to a hearing because they breached a discipline policy by bringing drugs to school, by sexually assaulting a girl in the building, or beating down a teacher or student because they looked at them wrong, it has nothing to do with economics. You know, a lot of it is home training. A lot of it I think has to do with the music. We are too sexually explicit, and these kids buy into everything. Some kids see a whole lot at home, starting with kindergartners who come to school. Some of them will tell you what their parents are doing, to what is on TV, or they take them to the movies, or they see it outside. That has nothing to do with economics. . . . I think we still need to teach our children history, to let them know what their ancestors did to get them to where they are now. You know, right now on some of the college campuses here-it was interesting to hear some of these 19- and 20-year-olds talking about, "gotta go to the library and get the book, Miseducation of the Negro." How long has that book been around? . . . So there is a connection, and now it is clicking. But it took all this time, which is sad.

Liz locates the cause of black misbehavior and crime in culture that has been degraded over time. In her estimation, that degradation is reflecte in unstructured family life and early childhood exposure to sex and violence through music, television, and movies and by witnessing the illicit behavior of others. In one respect, Liz's comments parallel those of conservative critics of black popular culture with whom she would not consciously ally (e.g., D’Souza 1995). Liz constructs a causal narrative about attenuated access where the increasingly violent and antisocial "code of the street" chases retail stores (and by extension, many middle-class families) away from Black Milwaukee. Likewise, critics suggest that individuals who inhabit disadvantaged positions are in many ways complicit in that disadvantage.

However, in another respect, Liz's comments reveal a black nationalist framework through which she views the complex relationship between social structure, human agency, and inequality in disadvantaged settings (see Massey 2002; MacLeod 1995; Ogbu 1994). She makes a significan departure from culture-of-poverty critics by suggesting that the way out of pervasive social malaise is through deeper immersion in black culture rather than through its abandonment. That is, rather than chiding black culture for an inherent inability or refusal to adopt "norms of decency," Liz advocates for more systematic study of black cultural history.

Another response to attenuated access that emerges from black nationalist ideology involves critical comments about the racist attitudes implied by managerial actions in stores that serve Black Milwaukee. Tim, the farm stand owner and also a former district manager of a fried chicken fast food chain, offers such a critique based on his fast food management experience.

Now all the stores on the north side were stores that the company had looked at as having the worst managers, the worst equipment, the worst everything in the stores, and they were just draining these stores and not putting anything into them. They had the attitude, "Because the stores are on the north side, and there is so much crime over here and this, that, and the other, we are always going to have high food costs. These stores are going to generate a lot of income and a lot of sales, but the bottom line is they're never going to be real good [profitable because of the theft and all that stuff." When I took over those stores . . . the firs thing I 
did was rehire the management and train them. I just hired good managers and good personnel. We started getting better equipment. I put in requests for new equipment because we had all the bad stuff and the south side stores and the suburban areas had all the good stuff. And they didn't hardly have any kind of earning potential. . . People [in Black Milwaukee] want good food just like anybody else. You have to give them something good, and they are going to respond.

Tim appears to invert the causal ordering offered by other informants by assuming consumer actions to be relatively benign and critiquing the behavior of management. He suggests that stores in Black Milwaukee are underdeveloped by management. Convinced that black-area stores cannot be profitable management siphons off their revenues and redistributes them as capital improvements to white-area stores. For Tim, this underdevelopment process makes high costs for black-area stores a self-fulfillin prophecy. High operating costs do not originate with the customer base. They are a virtually inevitable outcome of aging equipment and unqualifie personnel. Although both Tim's and Liz's responses emerge from a black nationalist ideology, Tim places the onus on management and their assumptions about doing business in Black Milwaukee. Consequently, Tim began his farm stands as a market-based response to unmet demand for fresh produce.

A fina black nationalist response to attenuated access takes the form of a racial chauvinism that attitudinally repositions informants without altering their structural position. For some informants living in Black Milwaukee, the small/microsized stores owned or operated by "foreigners" are a site of contention over community resources. These retail outlets frequently become storehouses of ethnic group resentment rather than mere storehouses of products. Shoppers in Black Milwaukee are very critical of small/microstores regarding the quality of their merchandise and service. Yet, explicit or implicit in many critiques is a racial and ethnic chauvinism that prevails upon the very racial hierarchy it purports to challenge. The "middleman minority" tensions (Bonacich 1973) bound up in legitimate critiques of disadvantaged consumer status are articulated most clearly by Alonzo and Ms. Bernice, two informants who are quite different from each other in personality and presentation yet who converge on their consumer strategies and the political ideology from which they derive. Alonzo, a (a working class black male who lives in a black neighborhood) asserts,

Whenever I buy some food, the place gots to be clean. Not sometimes it's clean and sometimes it ain't. . . . I just don't mess with [foreigners], and I just don't mess with corner stores when it comes to my meat. I gotta be at a place where that's what they do. They sell meat and groceries - meat and groceries.

Ms. Bernice (a working class black female who lives in a black neighborhood) says,
All them foreigners . . . come in here and just take over everything. . . . Meat be so bad. That's why I won't hardly go to them.

Alonzo's critique of microstores is primarily focused on the quality of the goods, cleanliness of the stores, and services available. Yet he implicitly asserts, and Ms. Bernice explicitly reasserts, a localized ethnic hierarchy that places immigrants, who are actually often from India and Pakistan, in the somewhat ironic role of colonizer. These informants' focus on meat as the product category in which their anger over colonization is expressed is, of course, due to its longstanding symbolic power to express social hierarchy (Harris 1985).

Certainly, many of the corner stores Alonzo refuses to patronize for food are also black owned. Yet black owners of what one informant labels "ghetto stores" are rarely subject to the colonizer critique. The dynamics involved in ethnic group battles over resources are, of course, complex and multifaceted (e.g., Olzak 1992), but the belief that new immigrants "take over" resources like jobs and businesses is widespread (Armbruster, Geron, and Bonacich 1995). Many black consumers express concerns about the treatment they receive at the hands of the mostly nonblack employees of corner stores (Chin 2001; Lee 2000, 2002). The much publicized shooting death of a black girl alleged to be shoplifting by a Korean immigrant store owner in Los Angeles, and the owner's subsequent sentence to community service and probation, represent an oft-repeated cautionary tale about the status of blacks in the marketplace and before the law (Chang 1993). But as evidenced in the statement by Ms. Bernice, tensions between blacks and immigrants, who "come in here and just take over everything," at least in part, reflec widespread angst about the perceived loss of community resources to out-groups. It creates a causal narrative about attenuated access to food that scapegoats a racialized other for a perceived loss of community resources, and perceived powerlessness to protect them, and is frequently used in service of the separatism called for by some versions of black nationalism.

\section{NORMATIVE POLITICAL IDEOLOGY IN CONSUMER RESPONSES TO ATTENUATED ACCESS}

The 20 yr. between 1970 and 1990 produced an extraordinary expansion of ghetto neighborhoods in Milwaukee. Although Milwaukee may be extraordinary, it is not unique in its rapid growth of predominantly black neighborhoods suffering from extreme poverty (Downs 1997). The decline of heavy manufacturing in the rust belt and the high (and essentially stagnant) residential segregation between blacks and whites since the 1970s are both highly implicated in the severe concentration of poverty common in predominantly black neighborhoods currently (see Krivo and Kaufman 1999).

Nationally, as ghettoization, which began in earnest in 
the 1940s, has functioned to concentrate poverty among a large percentage of the metro area's black residents, so, too, has it functioned to concentrate wealth and political power among a comparatively small percentage of the area's blacks. The current degree of wealth inequality among blacks is unparalleled in U.S. history (Oliver and Shapiro 1995). Of course, concentrated wealth in black America must be understood in relative terms, as African Americans control little net wealth in the United States. Using an assetbased rather than income-based poverty line, Shapiro (2004) find that over half of all black families were poor in 1999. Nonetheless, middle- and upper-middle-class blacks, just as in other racial and ethnic groups, have sought to convert their wealth into residential and institutional access, often (though not exclusively) in predominantly white settings. However, despite evidence of increased suburbanization among African Americans since the 1970s (Alba and Logan 1993; Farley and Frey 1994), suburban outmigration to better resources is often short lived, as whites respond by abandoning inner-ring suburbs, frequently taking municipal and state resources with them (Farley et al. 1978; Massey and Denton 1993).

It is in this context of rapidly concentrating urban poverty that early consumer research began to emerge about the specifi plight of ghetto residents in the marketplace, beginning in the late 1960s. David Caplovitz's (1967) classic, The Poor Pay More, brought marketplace inequality-or consumer disadvantage - and the issues surrounding attenuated access to goods and services to the attention of scholars in the business disciplines. Owing much to Caplovitz's work, Andreasen (1975) provides perhaps the most important insight into consumer disadvantage, namely, both functional and elemental definition of the concept. That is, he provides a general descriptor of the consumer disadvantage phenomenon and its constitutive elements - characteristics ascribed to the consumer, characteristics of the marketplace itself, and unethical behavior on the part of sellers - that frame research on the topic. The subsequent scholarly investigation of consumer disadvantage has developed primarily around identifying traits of the disadvantaged, such as age, poverty, literacy, and ability to process information.

The predominant focus on traits of the disadvantaged, however, has been critiqued as deterministic and reductionist, leaving aside questions about the broader social and cultural dynamics that produce and reinforce disadvantage (see Lee, Ozanne, and Hill 1999). In response, many interpretivists, drawing from the work of French sociologist Pierre Bourdieu as well as postmodern theory, have investigated the experiences of inequality in the marketplace at the nexus of gender, class, culture, and nationality (e.g., Dobscha and Ozanne 2001; Firat and Venhatesh 1995; Holt 1998; Peñaloza 1994). Likewise, our claim, based on this investigation, is that the widely acknowledged pattern of black ghettoization is a structural feature of urban settings that constitutes a material basis for the emergence of competing ideological factions within black communities. That is, a dual and self-reinforcing concentration of wealth and poverty has helped create the structural inequality prevalent in black neighborhoods that ultimately exacerbate longstanding competition over the ideological direction of the struggle for racial equality, all expressed through consumption.

Our research indicates that these competing ideological factions in the setting construct and reconstruct relations with each other through the act of provisioning. More specificall, informants in this sample approach provisioning with preexisting normative political ideologies that help them make sense of an ongoing stream of data about how best to distribute their limited temporal and economic resources in a setting infused with systemic disadvantages. It helps them interpret whether (and which) people and organizations aid or antagonize their provisioning efforts. At a less visible level, ideology also grounds their assumptions about the relative priorities of benefit accruing to their households and the broader community as a result of their provisioning behavior. In this way, ideology is central in grounding specifi manifestations of provisioning behavior. Ideological distinctions, for instance, may suggest quite different criteria for evaluating store choice, even among families of similar socioeconomic means. One middle-class family exits or outmigrates from Black Milwaukee altogether, viewing social integration in residence, education, and the marketplace as the desired culmination of the struggle for racial equality. Another similarly situated middle-class family find exit much less desirable, based on assumptions about its importance in cultivating black institutional life. Ideological distinctions may also result in two consumers having quite different understandings of the same provisioning experience. For instance, while food shoppers widely criticized ghetto stores for exorbitant prices, lowquality merchandise, and poor service, these justifiabl criticisms became for some part of a broader political critique aimed solely at immigrant-owned stores.

Provisioning, however, is not simply shaped by preexisting ideological forces in a deterministic manner. Based on this research, we go further in claiming that provisioning also functions in part to shape and reshape ideology itself. Informants call on their provisioning experiences to construct a causal narrative about the distribution of goods and services. They draw from their shopping experiences in constructing an ideological narrative about who is implicated in attenuated access, and ultimately about their relationship with the culpable party and others. Black informants who confront attenuated access often frame their own provisioning behavior as an act of stewardship to their households and/or to the broader black community. They, in turn, frame the behavior of some others as antagonistic to their interests, as well as to the interests of the black community. Normative political ideology functions to construct the terms of stewardship and antagonism.

Informants call on their provisioning experiences to help construct an ideological basis for determining political allies and political antagonists. Informants who adhere to black liberal ideology, whether they are working-poor residents 
of Black Milwaukee unable to exit or well-to-do outmigrants, see sovereignty, expressed as the free exercise of choice, as the primary feature on which their devotion to their households and their stewardship of the black community is based. As such, those who value the expansion of choice to include people or places previously excluded are seen as allies and fellow stewards of Milwaukee's black community. Those who problematize their sovereignty, by rejecting their choices or advocating for restrictions on choice, are seen as antagonists. Informants who adhere to black nationalist ideologies see the development of relatively autonomous black social, political, and economic institutions (including families) as central to their conceptions of stewardship and devotion. Those who contribute to black institutional development through their provisioning are framed as allies and stewards. Thus, continuous social and economic engagement in black institutional life, even at the expense of rejecting superior alternatives, is especially emphasized. For instance, the presence of black-owned business remains an important political symbol, even when patronage of these stores is not behaviorally reinforced. Conversely, those who undermine the development of black institutional life by abandoning or retaining only fragmented ties to the black community may be framed as antagonists.

When viewing provisioning through the lens of normative political ideology, what emerges is a picture of household provisioning as a vehicle through which social relations come to be constructed and maintained. Some informants view their own provisioning as having explicitly political consequences, which, not surprisingly, they tend to frame as aiding the struggle for racial equality. Like Miller's (1998) North London shoppers, these shoppers also strive through their provisioning to be in relation with a set of desiring subjects. Outside their own households, the character of these social relations is structured in part by the political ideology underlying provisioning behavior itself. Consequently, shoppers seek to build and maintain relations with subjects who desire them in particular ways.

Black liberals seek to erect alliances inside and outside of Black Milwaukee based on their acceptance as social equals, as citizens who participate fully in every facet of community life. As much of what has come to represent citizenship and participation in community life in the United States is funneled through the marketplace in the post-civil rights era, many black liberals have come to see this arena as a critical battleground in the struggle for racial equality. Yet competing views of the marketplace, of citizenship, of racial equality itself, as well as structural features of the setting, hinder the creation of such alliances.

Black nationalists are certainly no less concerned with racial equality, and as such they seek to construct and maintain alliances to facilitate such an outcome. Black nationalist ideologues, however, generally conceive of racial equality and citizenship more collectively than their black liberal counterparts. Nonetheless, black nationalists (particularly community-based nationalists) indeed seek social relations outside of the black community grounded in their acceptance as corporate social equals, worthy of normal market relations. Inside Black Milwaukee, they seek to construct and maintain alliances with those who appreciate and share their commitment to developing black institutional life. Their efforts are frustrated by rapid social decay in Black Milwaukee and by what they see as a competing tendency, particularly among middle-class blacks, to abandon black institutional life.

Thus, for both black liberals and black nationalists, consumption is inscribed with political ideology, independent of whether it is clearly elucidated or consciously unavailable. In addition, political ideology is constructed partially, if not wholly, by reference to the consumption acts in which it is embedded.

\section{CONCLUSION: INEQUALITY, CONSUMPTION, AND POLITICAL IDEOLOGY}

This research presents an account of consumer behavior in a setting structured by economic, social, and cultural forces not typically seen in consumer research. However, rather than marginalizing its importance to consumer research, these features of the setting help to reveal the pivotal role of normative political ideology in everyday acts of consumption. We suggest that, in the struggle for equality, consumers in this setting have increasingly come to express and demonstrate their political ideologies through consumption acts at the very time their involvement in more traditional acts of political participation is decreasing.

When existing social relations such as race, class, and gender inequality take commodity form as market relations, as in attenuated access to goods and services symbolized by rotting fruit, green meat, and shelves without unit pricing in ghetto stores, even reflexiv and critical consumption inherits the logic of the marketplace. Consumers, through their provisioning, navigate these market relations, attempting to alter them in some ways, reinforce them in others. However, consumers do not stop there. Through their provisioning, they also rearticulate market relations back into social relations, both extant and aspirational. They make consumption choices about where to shop, what to buy, and for whom, often from a set of dominated alternatives. Their choices and subsequent descriptions of them articulate something about who they believe should benefi from their efforts, with whom they are aligned, and who they consider antagonists. In this research, we have highlighted this process of rearticulating market relations back into organic expressions of social relations. We hope that we have helped open the door to a broader theoretical approach to provisioning activities that will include not only the moral and political logics through which consumers view their behaviors, their settings, and themselves but also the political and social consequences of political ideology being funneled into expression primarily through market behavior. 


\section{LIMITATIONS AND FUTURE RESEARCH}

As with all research, this has its shortcomings, leaving unanswered questions as opportunities for future research. For instance, we have left essentially uninterrogated the category of neglect that has been identifie as part of the exit, loyalty, and voice framework. In addition, the focus on African-American consumers ignores a rapidly growing Hispanic population in the setting under investigation. The firs author's access to Milwaukee's Hispanic community was limited by a host of factors, and this must be considered a limitation of the present research and fertile ground for future research in multicultural settings. We also offer that the role of consumer culture in political participation represents an intriguing area for future research. It is widely acknowledged that participation in conventional political activities in the United States shows a long-term decline that is unlikely to rise without dramatic, even revolutionary, shifts in the structure of daily life (Putnam 1995).
What are the implications of declining conventional political participation at the very time that political ideology expressed through consumer culture is expanding so rapidly? How are the two forms of expression intertwined? In a postmodern consumer culture, as political expression is increasingly funneled into acts of commodity consumption, it becomes more likely that such acts function solely in the long-run interest of the market rather than in the long-run interest of the polity and that political alternatives will resemble the "me-too" products that line the aisles of superstores. If consumption is increasingly an expression of normative political ideology, then questions about who counts the votes when citizen-consumers vote with their wallets, and toward what end, remain unanswered. In an era of startling political apathy, the meaning of consumption as an expression of normative political ideology requires careful analysis, both from a consumer culture and from a political point of view.

\section{APPENDIX}

\section{DATA OF THE SAMPLE AND PROCEDURES}

TABLE A1

SAMPLING COMPOSITION

\begin{tabular}{|c|c|c|c|c|c|c|c|}
\hline \multirow[b]{2}{*}{ Social class } & \multicolumn{4}{|c|}{ Black informant } & \multicolumn{3}{|c|}{ White informant } \\
\hline & \multicolumn{2}{|c|}{$\begin{array}{l}\text { Resides in } \\
\text { Black Milwaukee }\end{array}$} & \multicolumn{2}{|c|}{$\begin{array}{l}\text { Resides outside of } \\
\text { Black Milwaukee }\end{array}$} & \multicolumn{2}{|c|}{$\begin{array}{l}\text { Resides in } \\
\text { Black Milwaukee }\end{array}$} & $\begin{array}{l}\text { Resides outside of } \\
\text { Black Milwaukee }\end{array}$ \\
\hline Upper middle class & \multicolumn{2}{|l|}{ Ellis, Liz } & \multicolumn{2}{|c|}{ Craig, Eric, Anne } & \multicolumn{2}{|c|}{$\begin{array}{l}\text { Empirically negligible cell; } \\
\text { ignored in this study }\end{array}$} & Katrina \\
\hline Middle class & \multicolumn{2}{|c|}{ Mr. Chandler, Florine } & \multicolumn{2}{|c|}{ Pat } & \multicolumn{2}{|c|}{$\begin{array}{l}\text { Empirically negligible cell; } \\
\text { ignored in this study }\end{array}$} & Maggie \\
\hline Working class/subsidy & \multicolumn{2}{|c|}{$\begin{array}{l}\text { Lester, Gary, Alonzo, } \\
\text { Ms. Bernice, Dianne, } \\
\text { Denise }\end{array}$} & \multicolumn{2}{|c|}{ Mary, ${ }^{a}$ Lisa, ${ }^{a}$ Josie $^{a}$} & Candy, D & & $\begin{array}{l}\text { Kevin, Kim, Shirley, Martha, }{ }^{a} \\
\text { Kris, }^{a} \text { Cindy, }{ }^{a} \text { Dorothy } \\
\end{array}$ \\
\hline \multicolumn{8}{|c|}{$\begin{array}{l}\text { NOTE. }-N=28 . \\
\text { aThese informants live and were interviewed outside of metropolitan Milwaukee. Pseudonyms have been used to protect privacy. }\end{array}$} \\
\hline \multicolumn{8}{|c|}{ TABLE A2 } \\
\hline \multicolumn{8}{|c|}{ INFORMANTS FROM LOCAL ORGANIZATIONS } \\
\hline Institution (pseudonym) & & \multicolumn{2}{|c|}{ Contact } & \multicolumn{2}{|c|}{ Data provided } & & Description of data \\
\hline \multicolumn{2}{|l|}{ Adult education program } & \multicolumn{2}{|c|}{ Arlene } & \multicolumn{2}{|l|}{ Interview } & \multicolumn{2}{|c|}{ Quality check on data, data on the setting } \\
\hline \multirow{2}{*}{\multicolumn{2}{|c|}{ Food Insecurity Group }} & \multicolumn{2}{|c|}{ Jenna } & \multicolumn{2}{|c|}{ Interview } & \multicolumn{2}{|c|}{ Introduction to emergency food distribution } \\
\hline \multirow{2}{*}{\multicolumn{2}{|c|}{$\begin{array}{l}\text { Emergency food providers discussion } \\
\text { group }\end{array}$}} & \multicolumn{2}{|c|}{ Jack } & \multicolumn{2}{|c|}{ Interview, secondary } & \multicolumn{2}{|c|}{ Data on retail food distribution } \\
\hline & & \multicolumn{2}{|c|}{ Numerous } & \multicolumn{2}{|c|}{ Participant observation } & \multicolumn{2}{|c|}{ Data on local emergency food provision } \\
\hline \multicolumn{2}{|c|}{$\begin{array}{l}\text { Community garden program, } \\
\text { farm stand co-op }\end{array}$} & \multicolumn{2}{|l|}{ Tim } & \multicolumn{2}{|l|}{ Interview } & \multicolumn{2}{|c|}{$\begin{array}{l}\text { Data on the setting, data on food acquisi- } \\
\text { tion, data on community gardening } \\
\text { efforts }\end{array}$} \\
\hline URBAN project, G\&D V & riety Store & Gary & & $\begin{array}{r}\text { Interview, } p \\
\text { observati }\end{array}$ & rticipant & Data on th & setting, quality check on data \\
\hline
\end{tabular}


[Dawn Iacobucci and David Glen Mick served as editors and Craig Thompson served as associate editor for this article.]

\section{REFERENCES}

Alba, Richard D. and John R. Logan (1993), "Minority Proximity to Whites in Suburbs: An Individual-Level Analysis of Segregation," American Journal of Sociology 98 (May), $1388-1427$.

Anderson, Elijah (1999), Code of the Street: Decency, Violence, and the Moral Life of the Inner City, New York: Norton.

Andreasen, Alan (1975), The Disadvantaged Consumer, New York: Free Press.

Armbruster, Ralph, Kim Geron, and Edna Bonacich (1995), "The Assault on California's Latino Immigrants: The Politics of Proposition 187," International Journal of Urban and Regional Research, 19 (December), 655-63.

Bauldrillard, Jean (1998), The Consumer Society: Myths and Structures, Newbury Park, CA: Sage.

Bell, Judith and Bonnie Maria Burlin (1993), "In Urban Areas Many Poor Still Pay More for Food," Journal of Public Policy and Marketing, 14 (Spring), 48-59.

Bennett, Lerone (1987) Before the Mayflowe, 6th ed., Chicago: Johnson.

Bonacich, Edna (1973), "A Theory of Middleman Minorities," American Sociological Review, 38 (October), 583-94.

Buel, Richard (1972), Securing the Revolution: Ideology in American Politics, 1789-1815, Ithaca, NY: Cornell University Press.

Caplovitz, David (1967), The Poor Pay More, New York: Free Press.

Carmichael, Stokely and Charles V. Hamilton (1967), Black Power: The Politics of Liberation in America, New York: Vintage.

Cha-Jua, Sundiata K. and Clarence Lang (1997), "Providence, Patriarchy, Pathology: Louis Farrakhan's Rise and Decline," New Politics, 6 (Winter), 1-29.

Chang, Jeff (1993), "Race, Class, Conflict and Empowerment: On Ice Cube's 'Black Korea,'” Amerasia Journal, 19 (Spring), 87-108.

Charles, Camille Zubrinsky (2001), "Processes of Racial Residential Segregation," in Urban Inequality: Evidence from Four Cities, ed. Alice O'Conner, Chris Tilly, and Lawrence Bobo, New York: Russell Sage Foundation, 217-21.

Chin, Elizabeth M. Liew Siew (2001), Purchasing Power: Black Kids and American Consumer Culture, Minneapolis: University of Minnesota Press.

Collins, Randall (1988), Theoretical Sociology, New York: Harcourt-Brace Janovich.

Davis, Allison B., Burliegh B. Gardner, and Mary R. Gardner (1941), Deep South: A Social Anthropological Study of Caste and Class, directed by W. Lloyd Warner, Chicago: University of Chicago Press.

Dawson, Michael C. (2001), Black Visions: The Roots of Contemporary African-American Political Ideology, Chicago: University of Chicago Press.

Daykin, Tom (1999), "\$10 Million Jewel-Osco Coming to Central City," Milwaukee Journal-Sentinel, April 29, 1, 8.

DeVault, Marjorie L. (1991), Feeding the Family: The Social Organization of Caring as Gendered Work, Chicago: University of Chicago Press.

Dobscha, Susan and Julie L. Ozanne (2001), "An Ecofeminist Analysis of Environmentally Sensitive Women Using Qual- itative Analysis: The Emancipatory Potential of Ecological Life," Journal of Public Policy and Marketing, 20 (Fall), 201-14.

Downs, Anthony (1997), "The Challenge of Our Declining Big Cities," Housing Policy Debate, 8(2), 359-408.

Drake, St. Claire and Horace Cayton (1945), Black Metropolis: A Study of Negro Life in a Northern City, New York: Harcourt Brace.

D'Souza, Dinesh (1995), The End of Racism: Principles for a Multiracial Society, New York: Free Press.

Eagleton, Terry (1991), Ideology: An Introduction, New York: Verso.

Elgin, Duane (2000), "Voluntary Simplicity and the New Global Challenge," in The Consumer and Society, ed. Douglas B. Holt and Juliet B. Schor, New York: New Press, 197-213.

Farley, Reynolds and William H. Frey (1994), "Changes in the Segregation of Whites from Blacks during the 1980s: Small Steps toward a More Integrated Society," American Sociological Review, 59 (February), 23-45.

Farley, Reynolds, Howard Schuman, Suzanne Bianchi, Diane Colasanto, and Shirley Hatchett (1978), "'Chocolate City, Vanilla Suburbs': Will the Trend toward Racially Separate Communities Continue?" Social Science Research, 7 (December), 319-44.

Feagin, Joe R. and Melvin P. Sikes (1994), Living with Racism: The Black Middle Class Experience, Boston: Beacon.

Firat, A. Fuat and Alladi Venkatesh (1995), "Libratory Postmodernism and the Reenchantment of Consumption," Journal of Consumer Research, 13 (September), 196-213.

Foner, Eric (1990), A Short History of Reconstruction, 1863-1877, New York: Harper \& Row.

Frazier, E. Franklin (1957), Black Bourgeoisie, Glencoe, IL: Free Press.

Griffin John H. (1961), Black Like Me, Boston: Houghton Mifflin Habermas, Jürgen (1985), The Theory of Communicative Action, Boston: Beacon.

Haines, George H., Jr., Leonard Simon, and Marcus Alexis (1971), "The Dynamics of Commercial Structure in Central City Areas," Journal of Marketing 25 (April), 10-18.

Harris, David R. (1999), "Property Values Drop When Blacks Move In, Because . . . : Racial and Socioeconomic Determinants of Neighborhood Desirability," American Sociological Review 64 (June), 461-79.

Harris, Marvin (1985), Good to Eat: Riddles of Food and Culture, New York: Simon \& Schuster.

Hirschman, Albert O. (1970), Exit, Voice, and Loyalty: Responses to Decline in Firms, Organizations, and States, Cambridge, MA: Harvard University Press.

Hirschman, Elizabeth C. (1993), "Ideology in Consumer Research, 1980-1990: A Marxist and Feminist Critique," Journal of Consumer Research, 19 (March), 537-55.

Holt, Douglas B. (1998), "Does Cultural Capital Structure American Consumption?" Journal of Consumer Research, 25 (June), 1-25.

(2002), "Why Do Brands Cause Trouble? A Dialectical Theory of Consumer Culture and Branding," Journal of Consumer Research, 29 (June), 70-90.

Horkheimer, Max and Theodor W. Adorno ([1944] 1996), Dialectic of Enlightenment, New York: Continuum.

Jargowsky, Paul (1997), Poverty and Place: Ghettos, Barrios and the American City, New York: Russell Sage Foundation.

Johnson, Karl, Stephen Percy, and Edward Wagner (1996), "Comparative Study of Food Pricing and Availability in Milwau- 
kee," report for the Food System Assessment Project, Center for Urban Initiatives and Research, University of Wisconsin-Milwaukee, Milwaukee, WI 53201.

Kaufman, Phil and Steven M. Lutz (1997) "Competing Forces Affect Food Prices for Low-Income Households," Food Review (May-August), 8-12.

Kozinets, Robert (2002), "Can Consumers Escape the Market? Emancipatory Illuminations from Burning Man," Journal of Consumer Research, 29 (June), 20-38.

Krivo, Lauren J. and Robert L. Kaufman (1999), "How Low Can It Go? Declining Black-White Segregation in a Multiethnic Context," Demography, 36 (February), 93-109.

Lee, Jennifer (2000), "The Salience of Race in Everyday Life: Black Customers' Shopping Experiences in Black and White Neighborhoods," Work and Occupations, 27 (August), 353-77.

- (2002), "From Civil Relations to Racial Conflict Merchant-Customer Interactions in Urban America," American Sociological Review, 67 (February), 77-98.

Lee, Renee Gravois, Julie L. Ozanne, and Ronald Paul Hill (1999), "Improving Service Encounters through Resource Sensitivity: The Case of Health Care Delivery in an Appalachian Community," Journal of Public Policy and Marketing, 18 (Fall), $230-48$.

MacLeod, Jay ([1987] 1995), Ain't No Makin' It: Aspirations and Attainment in a Low-Income Neighborhood, Boulder, CO: Westview.

Marable, Manning (1991), Race, Reform, and Rebellion: The Second Reconstruction in Black America, 1945-1990, Jackson: University of Mississippi Press.

Massey, Douglas S. (2002), "A Brief History of Human Society: The Origin and Role of Emotion in Social Life," American Sociological Review 67 (February), 1-29.

Massey, Douglas S. and Nancy A. Denton (1993), American Apartheid: Segregation and the Making of the Underclass, Cambridge, MA: Harvard University Press.

Mick, David Glen and Susan Fournier (1998), "Paradoxes of Technology: Consumer Cognizance, Emotions, and Coping Strategies," Journal of Consumer Research, 25 (September), 123-43.

Miller, Daniel (1998), A Theory of Shopping, Ithaca, NY: Cornell University Press.

Moses, Wilson J. (1996), Classical Black Nationalism: From the American Revolution to Marcus Garvey, New York: New York University Press.

Ogbu, John U. (1994), Black American Students in an Affluen
Suburb: A Study of Academic Disengagement, Mahwah, NJ: Erlbaum.

Oliver, Melvin L. and Thomas Shapiro (1995), Black Wealth/White Wealth: A New Perspective on Racial Inequality, New York: Routledge.

Olzak, Susan (1992), The Dynamics of Ethnic Competition and Conflic, Stanford, CA: Stanford University Press.

Omi, Michael and Howard Winant (1990), Racial Formation in the United States: From the 1960s to the 1980s, New York: Routledge.

Oswald, Laura R. (1999), "Consumption and Ethnogenesis of Middle-Class Haitian Immigrants," Journal of Consumer Research, 25 (March), 303-18.

Ownby, Ted (1999), American Dreams in Mississippi: Consumers, Poverty, and Culture, 1830-1998, Chapel Hill: University of North Carolina Press.

Peñaloza, Lisa (1994), “Atravesando Fronteras/Border Crossings: A Critical Ethnographic Exploration of the Consumer Acculturation of Mexican Immigrants," Journal of Consumer Research, 21 (June), 32-54.

Putnam, Robert (1995), “Bowling Alone: America's Declining Social Capital," Journal of Democracy 6 (January), 65-78.

Sandel, Michael (1996), Democracy's Discontent: America in Search of a Public Philosophy, Cambridge, MA: Harvard University Press.

Shapiro, Thomas M. (2004), Hidden Cost of Being African-American: How Wealth Perpetuates Inequality, New York: Oxford University Press.

Snow, David A. and Leon Anderson (1993), Down on Their Luck: A Study of Homeless Street People, Berkeley: University of California Press.

Trotter, Joe William (1985), Black Milwaukee: The Making of an Industrial Proletariat, 1915-45, Urbana: University of Illinois Press.

Wallendorf, Melanie and Eric J. Arnould (1991), "“We Gather Together': Consumption Rituals of Thanksgiving Day," Journal of Consumer Research, 18 (June), 13-32.

Wilson, William Julius (1987), The Truly Disadvantaged: The Inner City, the Underclass, and Urban Policy, Chicago: University of Chicago Press.

- (1996), When Work Disappears: The World of the New Urban Poor, New York: Knopf.

Withey, Michael J. and William H. Cooper (1989), "Predicting Exit, Voice, Loyalty, and Neglect," Administrative Science Quarterly, 34 (December), 521-39. 